\title{
Teachers as Psychologist: Experience in Beginner Level of Creative Writing Classes Using Behavior Modification
}

\author{
Anas Ahmadi \\ Universitas Negeri Surabaya \\ Surabaya, Indonesia
}

\begin{abstract}
This article is a part of an investigative research report on students' behavior towards creative writing using a psychological approach. This research was carried out for one semester (4 months). This study aims to explore experiences in beginner level creative writing classes. As we all know, there have been many studies on creative writing, but only a few which discussed creative writing using psychological approaches. This research focused on problems in learning to write creatively and behavior modification practices in creative writing using a behavioral psychology approach. The method used was qualitative involving 81 participants from the Indonesian Language and Literature Department, Universitas Negeri Surabaya, East Java, Indonesia. Interviews and questionnaires were used as data collection techniques. The questionnaire is used to capture the difficulties of participants in creative writing. Meanwhile, the interview is used to capture the difficulties experienced by students in creative writing. Interviews are conducted with reflective and flexible techniques. The research findings show that (1) 70 participants answered that the difficulty in creative writing mostly occurred due to psychological problems; and (2) 51 participants answered that their weakness in creative writing mostly because they are lack of talent.. Other findings indicate that students are very enthusiastic about learning creative writing using psychological approaches because this approach is more mental.
\end{abstract}

Keywords: teacher, psychology; psychowriting; creative writing; behavior modification.

\section{Introduction}

The teaching of writing in the context of language learning is the most complex (William, 2018; Atlee, 1995) when compared to listening, reading, and speaking. Writing does require excellent skills to produce excellent writing. Someone who has excellent skills will produce more excellent writing. Therefore, the myth 
emerged that being a writer is indeed not easy because "beginning writers must make decisions about what to write" (William, 2018, p. 1). This myth is sometimes used as a reference by people who find it difficult to write resulting in a real failure in writing.

Beginner writers, according to Swander, Leahly, \& Cantrell (2007), mostly find it difficult to write because they consider writing as a talent and cannot be taught. In writing lessons, the strategies that are raised by teachers are very important and most decisive (Baroudy, 2018) success in learning. The strategies raised by the teacher are very important so that students are able to be motivated in writing. To facilitate someone in writing, White and Arndt (1991) tried to bring up the stages of writing, namely (1) drafting, (2) structuring, (3) reviewing, (4) focusing, (4) generating, and (5) evaluating. These writing stages generally appear in learning to write.

Based on studies conducted by some researchers, several studies conducted to improve writing skills raised the topics of checklist strategies (Jagaiah, Howard, and Olinghouse, 2019), scaffolding (Cabell, Tortorelli, \& Gerde, Matsumura, and Correnti, 2013), feedback (Wang, 2017), interactive (Roth \& Dabrowski, 2014), integrative (Yoo, 2017), psychological (Wilson, 2008; Bueno, 2018), dialogic (Kesler, 2012), stories (Barbeiro, 2005), and philosophical (Jordan-Baker, 2015). All writing strategies are raised in order to optimize learning to write.

In Indonesia, researchers have conducted research on creative writing, including Tatat (2017); Darmawan, Hartati, \& Mulyasari (2013); Wahyuni (2010). None of the researchers focused on creative writing from a psychological perspective although, in fact, it is one of the interesting fields in research on writing. Forgeard, Kaufman, \& Kaufman (2013, p. 330) stated, "the study of creative writing is a relatively new and interesting field of psychological research". However, as it is well known, creative writing studies that are reviewed through a psychological perspective are still rarely conducted. In providing material about creative writing, a teacher is not only able to teach writing material, but he must also have an understanding of the science of psychology. Matters relating to character, soul, personality, fairness, transformation, therapy, and inspiration, are areas of psychology that must be recognized and understood by a teacher (Prilleltensky, 2014; Martin, 2014). In this case, as a psychologist, the teacher is able to recognize students when they have psychological problems concerning learning. A teacher, at the same time a psychologist, understands, recognizes, observes, and provides treatments to students (as clients) so that learning can be optimal. A teacher who has psychological stock is expected to provide better learning compared to teachers who do not have any understanding in the field of psychology. One of them is a teacher who is able to give aspirations (Solheim, 2019) to his students. Therefore, in learning in tertiary institutions, there are educational psychology courses so that students will understand the psychological context related to education and learning. Likewise with the teacher because learning in a class setting is not only required him to teach the material but also to understand his students psychologically. 
To date, the study of creative writing and psychology has been conducted by Awuzie (2018), Wells et al. (2018), Bermann (2003), Dunn (1994), Karlen \& Compagnoni (2016), Pollington, Wilcox, \& Morrison (2001), Billig (2011), Gardner (2014), and Piirto (2009). From all the research on writing a psychological perspective, no one has examined the factors that cause difficulties in writing. In fact, the difficulty of writing from a psychological perspective is very interesting because it initially digs up information in writing difficulties experienced by students. Then, after the factors causing difficulties are found, they are treated and students are able to improve their writing abilities optimally. Related to this, this research explores the experience of teachers as a psychologist. In line with Emily's (2009) view that one's individual experience can be used as research as well as data. In this case, the teacher as a psychologist tries to examine more deeply the learning difficulties experienced by students (as clients) who are categorized as novice writers and provide psychological therapy in the context of writing.

\section{Literature Review \\ 2.1 Psychowriting}

Writing and psychology are two fields of science that have closeness. Writing is the process of expressing ideas in written form, whereas psychology in this context is the process of pouring ideas which is a mental work (Ahmadi, 2015; Ahmadi, Darni, Murdiyanto, \& Hariyati, 2019; Ahmadi, Darni, \& Murdiyanto, 2019; Ahmadi, et al. 2019). The closeness between writing and psychology gives rise to an interdisciplinary study of psychological perspective writing in which it reviews aspects of psychology: mood, personality, soul, thoughts, characters, and ideas (Russ, 2009). Linking writing with psychology is not an easy study to do (Kaufman \& Kaufman, 2009) because it juxtaposes two disciplines from different families. However, that is where the uniqueness and excitement relied upon. So far, it is still rare for psychologists to study the context of writing. Conversely, there are still not many writers who associate writing with psychology. Therefore, the interdisciplinary study between writing and psychology is expected to provide breakthroughs and contributions that are more concrete and better than writing studies in a monodisciplinary context. In addition, Nissani (1997, p. 201) shows that interdisciplinary studies have a high degree of flexibility in terms of interpretation. In this context, researchers termed psychowriting which means writing psychological perspectives, in which the researcher focuses his study on three main aspects.

First, psychowriting that is related to the creative process of the writer. In this aspect, a researcher focuses his study on the author: biography, daily life, character, or psychological condition. To obtain data, the researcher can use interview techniques or documentary analysis about the author. For this type of psychowriting, it does seem heavy because the researcher must be able to conduct interviews with the author so that research results can be more accountable for their scientific level.

Second, psychowriting related to creative work. In this aspect, a researcher focuses his study on creative work. Through creative work, a researcher explores 
personality types, psychological tendencies of writers contained in the creative work, or psychological elements contained in the creative work. For this type of psychowriting, the researcher uses data from creative works in the form of short stories, novels, drama, or poetry. This study is mostly conducted by researchers because it is easier and more feasible in terms of data collection and data processing.

Third, psychowriting is related to reader response. In this aspect, a researcher focuses his study on the response of readers after they read creative work. Through the reader's response, the researcher can get data about how the reader responds to creative work which is related to the reader's personality. Readers' responses in psychowriting are divided into two categories, namely professional readers and general readers. Professional readers are readers who have authority in the field of psychology or the field of writing. The general reader is someone who really likes psychology or writing but does not have authority in the field.

This logic is based on empirical facts that writing cannot be separated from psychology. Someone who writes must use their thoughts to come up with ideas since the mind is a part of psychology. The concretization of the thinking process gave birth to writings (Ahmadi, 2015) which contains linguistic symbols. Writing requires the help of psychological science in terms of pouring ideas and creativity. Therefore, someone whose psychological condition is normal will be able to write normally too. Conversely, if someone is in a less normal condition, the writing will also show the abnormality (psychological context).

Related to that, writing does show one's personality (Ruffner \& Burgoon, 1981). Conversely, a person's personality is also evident from his writings, both explicitly or implicitly. Piirto (2009) underlines that when someone writes, he represents a personality. Correspondingly, many psychologists also link the relationship between writing and psychology, especially figures in psychoanalysis such as Jung $(1934,1956,1961,1964,1966,1969)$ and Freud (1910, 1955). Both Jung and Freud stated that humans are inseparable from the unconscious, either personal unconscious or collective unconscious which also happened in writing.

\subsection{Personality Psychology}

As a study in writing, psychowriting is closer to personality psychology than other types of psychology such as social psychology, environmental psychology, religious psychology, or mass psychology. Personality psychology is essentially psychology that studies the types of personality, character, or characteristics (Eysenck, 1997; Feist \& Feist, 2006; Hall, Linzey, \& Campbell, 1998; Ashton, 2013; Carducci, 2009). This type of psychology considered a pioneer of psychology in the following years.

Personality psychology initially talks more about generic personality types so it is rather difficult to produce the right findings. Nevertheless, personality types raised by Hippocrates and in subsequent developments popularized by Galenus 
about four personality types, Choleric, Sanguine, Phlegmatic, Melancholic (Jouanna, 2012) made a positive contribution in the development of personality types. Nevertheless, in today's development, personality types are more specific so they can be more precise in interpreting one's personality.

The most well-known personality psychology includes psychoanalysis pioneered by Freud, Jung, Fromm; existentialist pioneered by Sartre, Heidegger; behaviorists pioneered by Skinner, Pavlov, Watson, and humanists pioneered by Maslow (Crowne, 2007; Engler, 2013). Personality psychology reveals the uniqueness of a person as an individual. However, as explained by psychology practitioners, the study of psychology only reveals a small part of the human personality. Therefore, in this study, psychology is used only to understand a small number of psychological problems.

\subsection{Psychology of Behaviorism}

Behavioral psychology is psychology that further emphasizes the view of the environment as the main factor and determinant of one's personality (Watson, 1913; Pavlov, 1927; Skinner, 1957; Gross, 2010; Natsoulas, 2018). Behavioral psychology is the psychology that rejects the view of existential psychology which holds that a person's personality is dominated by 'self' which is a person's internal factors. Behaviorism is also considered as the psychology of awareness because it considers that treatment will change a person's behavior.

Nowadays, the psychology of behaviorism appears in various branches of study, among which are behavior modification studies. Behavior modification supports that behavior change is an effective technique in learning psychology, but is also used in the context of education, teachers, lecturers, and parents. One of its main advantages is that it can be observed and is more easily applied in various aspects of research (Martin \& Pear, 2015; Miltenberger, 2011). Therefore, nonpsychologists who have an interest in the study of psychology can use behavior modification in their studies.

Behavior modification that is currently developing in the psychology of behaviorism is inseparable from the influence of Skinner and Pavlov (Labrador (2004) who are the pioneers of behavioral psychology. Lachenmeyer and Olson (1990) stated that behavior modification is a combination of behavioral psychology and cognitive psychology so that this study is better, more effective, and flexible in its use in research. Today, behavior modification also enters the educational context (Wheldall, 1992) so teachers can use it as an alternative in dealing with students' psychological problems in classroom learning.

\section{Methods}

This study used qualitative methods because it exposes more descriptive, analytical, thematic, and interpretative data (Sandelowski, 1998; King \& Brookes, 2018; Creswell, 1994; Creswell \& Guerterrman, 2019; Ahmadi, Ghazali, Maryaeni, \& Dermawan) so that the data presented are more dominant in verbal data instead of statistics. In this study, the researcher acted as the teacher as well as the instructor. Meanwhile, the participants were 81 students of the Indonesian 
Language and Literature Department, Universitas Negeri Surabaya, Indonesia. They are students who are enrolled in Writing Skills courses. Following is the visualization of the students' data.

Table 1: Distribution of participant

\begin{tabular}{|l|l|l|l|}
\hline Class & Number of students & Female & Male \\
\hline A & 40 & 34 & 6 \\
B & 41 & 32 & 9 \\
\hline
\end{tabular}

The data were collected using questionnaires and interviews. In this research, the questionnaire is used to capture the difficulties of students in creative writing while the interview is used to capture the difficulties experienced by students in creative writing. Interviews are conducted with reflective and flexible techniques. Data analysis techniques include the stages of identification, classification, reduction, exposure, and verification (Miles \& Huberman, 2014). At the last stage, the exposure of research data was carried out. As for the research assessment, the researcher adapted Martin \& Pear (2015) which relates to (1) the screening phase, (2) the pre-program phase, (3) the handling phase, and (3) the follow-up phase. In this study, the assessment only used three phases, namely networking, handling, and follow-up.

In interviews, the researcher referred to the views of Sinha \& Back (2014, p. 273), which uses interviews that are 'close and sincere' so that students may feel comfortable. In this case, the interview technique is more psychological than the ethnographic interview. Closeness and familiarity are established by the researcher during the interview so that students may feel comfortable and safe in providing the information needed. Therefore, the interview will run naturally and they will easily provide information to the researcher. After going through the stages of data analysis, triangulation was carried out so that research results can be scientifically justified (Silverman, 2000) ontologically, axiologically, and etymologically. Consequently, the results of the research can be more robust and strong theoretically and methodologically.

\section{Result and Discussion}

\subsection{Filtering Phase}

The filtering phase is related to the initial data mining carried out by the researcher to students. In this phase, the researcher conducted student data selection (in this case, students are considered clients and the researcher as a psychologist). The screening phase was carried out in the first and second months, namely August and September 2018. In the screening phase, the researcher asked students to fill out forms consisting of general information such as name, gender, age, address, telephone, hobbies, things they like, and things that are hated. The general information data is used to recognize and understand students' social-cultural context in general. Besides, if a student does experience problems with a psychological context, it will be easier to handle because it has been recognized by the researcher from the beginning.

After getting general information about student data, the next step was filling out the questionnaire by students. Researchers gave questionnaires containing 4 
questions to students. The questionnaire is related to difficulty in writing. Question No 1: Are you having difficulty in creative writing? Based on the results of the questionnaire, 70 students answered having difficulty in creative writing; 5 students answered that they did not experience difficulties in creative writing; and 6 students said they did not know. Question No 2: Are psychological factors the main causes of writing difficulties? The results of the questionnaire show that 77 students answered yes; 3 students answered no; and 1 student said did not know. Question No 3: Have you ever heard of a psychological perspective writing strategy? "Based on the questionnaire results, 81 students answered yes; 0 students answered no; and 0 students said they did not know. Question No 4: Do you like to read psychology books? Based on the results of the questionnaire, 79 students answered yes; 10 students answered no; and 2 students said they did not know. In addition to closed questionnaires, there are also open questionnaires that contain complaints about difficulties in creative writing. Of the 81 students who submitted complaints about the difficulties of creative writing, the exposed data is as follows.

Table 4.1 Difficulties of students in creative writing

\begin{tabular}{|l|l|}
\hline Difficulty in creative writing & Participants \\
\hline No creative writing talent & 51 \\
Not confident when writing creatively & 9 \\
Difficult to bring up inspiration/ideas & 5 \\
Media never publish creative writing & 3 \\
It's hard to start creative writing & 2 \\
Have no interest in creative writing & 3 \\
Creative writing takes a lot of time to do because it & 3 \\
uses metaphorical language & \\
Always fails when writing creatively & 3 \\
Often stopped during creative writing process/stuck \\
in creative writing
\end{tabular}

The questionnaire filling stage is used to understand and recognize the difficulties of students in relation to creative writing. Difficulties in creative writing are more directed to the psychological context. That way, the researcher can recognize and understand the factors that cause writing difficulties experienced by these students. After selection through questionnaires, the researcher interviewed students in relation to difficulties when writing creatively. The interview uses the 'close and sincere' model which refers to Sinha \& Back's view (2014, p. 273). In this session, the researcher asked the students to form groups of 10 students randomly (male and female gender). Each group was visited by the researcher and asked about matters relating to difficulties in writing. The following are the results of the interviews.

First, $60 \%$ of students tend to express that they have difficulty in writing creatively because they feel they have no talent in writing. Since childhood, they are not really interested in creative writing. They reveal that creative writing is not like scientific writing, which is easier in stages. Likewise, with the steps of writing, academic writing is indeed more structured and systematic, making it easier for students to write. Compared to scientific writing, creative writing has 
a higher level of difficulty and is more complex which makes them experience difficulties in creative writing.

Secondly, $20 \%$ of students tend to express that they feel insecure about creative writing. This is because they rarely write creatively so when they read their work, they are embarrassed to publish it because the writing is considered not good. For this reason, they did not publish it. In addition, students' lack of confidence increases when their writing is read by friends. When their friend gives less appreciative criticism, it causes the student who writes creatively becomes more insecure.

Third, $10 \%$ of students' tendencies reveal that difficulties in creative writing are due to the absence of ideas, traffic jams, or laziness. This is indeed the cause of creative writing. Students feel that creative writing requires great ideas in order to produce good writing. If you do not have a great idea, it will be hard to produce writing.

\subsection{Handling Phase}

The handling phase is the phase that relates to the provision of treatments after the teacher knows, recognizes, and understands students' difficulties in writing (through questionnaires and interviews). This handling phase was carried out in the third and fourth months, namely September and October 2018. In this phase, the researcher as a teacher as well as a psychologist provided treatments to students, which is referred to as behavior modification, in order to change students' behavior in creative writing. The researcher conducted observations and also monitored clients (Martin \& Pear, 2015), which in this case are students. The researcher observed and monitored students in the class during creative writing learning. When making modifications, the researcher immediately provided intervention to students. Thus, behavior modification is expected to occur.

Students as personal have a unique character and are different from other students. Likewise, each student also has different difficulties in terms of creative writing. Therefore, students also need different behavior modification treatments from their teacher. Because of the large number of students, behavior modification is made communally by considering the same aspects of creative writing difficulties. Based on the results of behavior modification and the provision of interventions to students in relation to creative writing, the following results are obtained. 
Table 4.2 Modification of student behavior

\begin{tabular}{|c|c|}
\hline Difficulty in creative writing & Behavior modification \\
\hline No creative writing talent & $\begin{array}{l}\text { Convince students that talent contributes } \\
\text { only } 10 \text { percent of success in writing. The } \\
\text { rest is about tenacity and hard work. }\end{array}$ \\
\hline $\begin{array}{l}\text { Not confident when writing } \\
\text { creatively }\end{array}$ & $\begin{array}{l}\text { Convince that all writers are from zero. } \\
\text { Nobody immediately became a famous } \\
\text { writer. }\end{array}$ \\
\hline $\begin{array}{l}\text { Difficult to bring } \\
\text { inspiration/ideas }\end{array}$ & $\begin{array}{l}\text { Ask students to read more creative } \\
\text { writing, join the writing community, and } \\
\text { study with seniors who have succeeded } \\
\text { in creative writing. }\end{array}$ \\
\hline $\begin{array}{l}\text { Media never published creative } \\
\text { writing }\end{array}$ & $\begin{array}{l}\text { Start sending writing to small media first } \\
\text { before sending it to a bigger media } \\
\text { company. }\end{array}$ \\
\hline $\begin{array}{l}\text { It's hard to start creative writing } \\
\text { Have no interest in creative } \\
\text { writing }\end{array}$ & $\begin{array}{l}\text { Spend more time in creative writing. } \\
\text { Generate interest by appreciating } \\
\text { yourself. }\end{array}$ \\
\hline $\begin{array}{l}\text { Creative writing takes a lot of time } \\
\text { to do because it uses metaphorical } \\
\text { language }\end{array}$ & $\begin{array}{l}\text { Read more literature in relation to } \\
\text { thesaurus, dictionaries, and } \\
\text { encyclopedia. }\end{array}$ \\
\hline $\begin{array}{l}\text { Always fails when writing } \\
\text { creatively }\end{array}$ & $\begin{array}{l}\text { Try to write continuously because when } \\
\text { it fails, we must be able to understand } \\
\text { the mistakes that cause failure }\end{array}$ \\
\hline $\begin{array}{l}\text { Often stopped during creative } \\
\text { writing process/stuck in creative } \\
\text { writing }\end{array}$ & $\begin{array}{l}\text { Write one part at a time. There is no need } \\
\text { to write the whole writing in one time } \\
\text { because sometimes a writer needs to do } \\
\text { adjustment in writing }\end{array}$ \\
\hline
\end{tabular}

The behavior modification is given to students so they can experience changes in behavior. Therefore, after giving behavior modification, the researcher provided assignments related to creative writing. Initially, the researcher provided material about writing creative short stories followed by the assignments. The assessment criteria of the assignments include writing about 1500 words, original titles, interesting, and providing novelty, and aesthetics. The creative writing assignments are done individually by students and collected within 7 days. During the work of writing a short story creative assignment, students may consult with the researcher, either through face-to-face or via email and/or social media. It is hoped that through this consultation the researcher can provide constructive input to students in relation to creative writing. Consultation is done directly, for example, discussion with the researcher is an effective and efficient medium in learning because students get solutions directly when facing problems and difficulties in writing. 
After 7 days, the creative writing assignments were collected and the researcher examined the creative writing assignments. Creative writing was assessed based on criteria that have been made by the researcher. After all the assignments are collected, the researcher gave input related to the results of students' creative writing. In order to understand and know changes in students' behavior during the creative writing process, the researcher provided a questionnaire related to the results of behavior modification. The questionnaire was given to students after they had completed their creative short story writing assignments. Based on the selection of questionnaires related to the effectiveness of student behavior modification in creative writing, the following data were obtained.

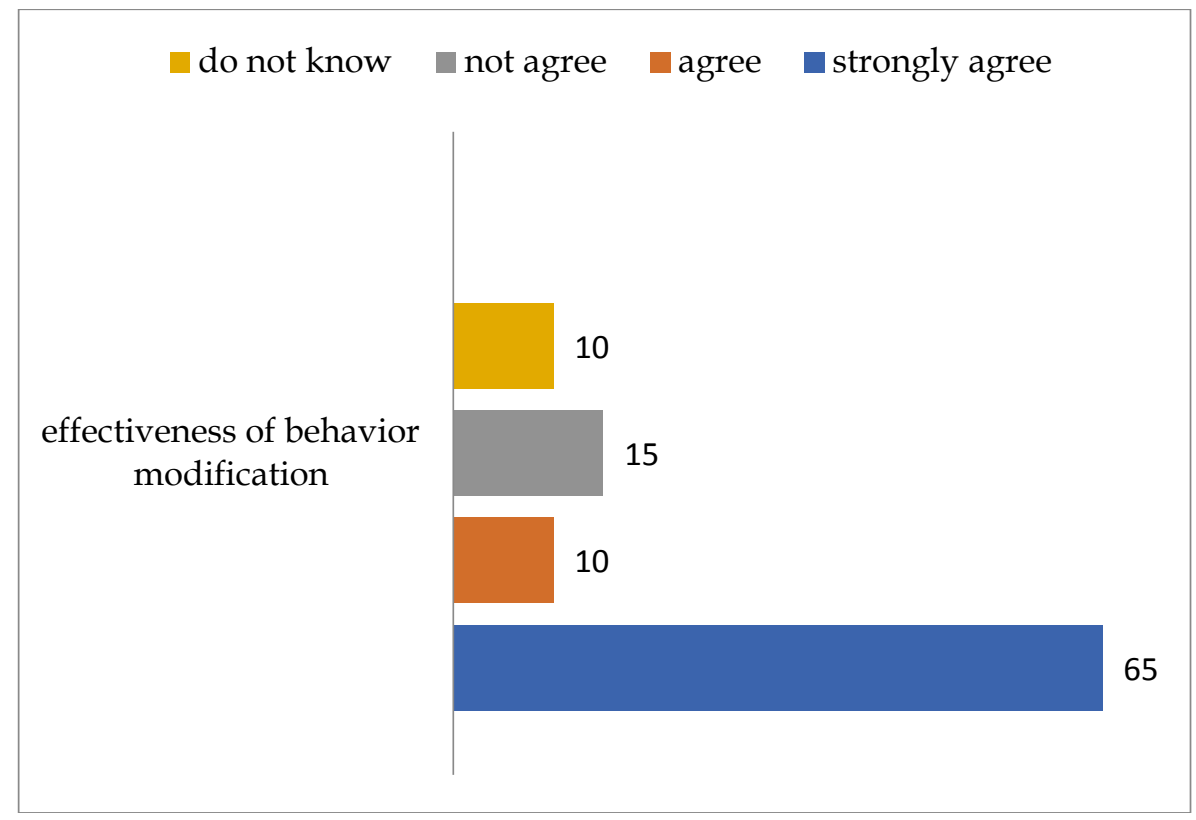

Figure 1: Effectiveness of modifying student behavior

Based on the table above, it appears that $65 \%$ of students as clients feel that behavior modification is effective in learning to write creatively. They strongly agree that behavior modification is effective in learning to write. $10 \%$ of students answered agree that behavior modification is effective in learning. $10 \%$ of students answered that they did not agree that behavior modification was an effective strategy in learning and 10\% answered that they did not know whether behavior modification was effective in learning or not. Based on the results of the questionnaire, it appears that for the effectiveness of learning in creative writing, behavior modification occupies 65 percent of success and effectiveness. Behavior modification given to students took place during the lecture so that the researcher can find any weaknesses in behavior modification. When finding deficiencies and weaknesses in behavior modification, the researcher immediately intervened in a better direction. The intervention is expected to support changes in student behavior in creative writing.

\subsection{Follow-up phase}

The follow-up phase is related to the final activity after giving behavior modification. This phase is the final stage in the study of behavior modification. The follow-up phase was carried out in late November. In this phase, the 
researcher provided improved behavior modification to students who are still experiencing difficulties in creative writing. The students were given additional material related to creative writing, especially in terms of exploring ideas, pouring ideas, and exploring writing. Besides, the researcher also provided input related to the psychological context so that students are motivated in writing. In this context, the researcher acted as a motivator (Greene, 2005). Through this stage, students can become more optimal in creative writing.

Students, who still felt that they have difficulty in creative writing, even though they have been given improvements in behavior modification, would be crosschecked. In this context, the researcher repeated the phase from the beginning, the filtering phase. The researcher conducted intensive (personal) interviews with students who are still experiencing difficulties in creative writing. Like behavioral psychologists, the stimulus given to students is expected to be positive and build high confidence in students. When a student gets a positive and appreciative stimulus from the researcher, he will give a good response. The response appears when the behavior modification that is raised by the researcher is experienced by students as a positive stimulus and not vice versa. Thus, psychological problems experienced by students can be handled quickly by the researcher. To be a student who is able to write creatively well and truly does need hard work. Piirto (2009) asserts that to be a reliable creator requires a reliable personality as well. Thus, the success of students in creative writing is largely determined by the students' personalities. If the student has a strong personality and high interest in creative writing, he will easily write creatively.

\section{Conclusion}

Teachers are psychologists in the world of education. Therefore, teachers are expected to be able to recognize, understand, and observe their students who are, in this context, considered as clients. When students experience difficulties concerning creative writing, as psychologists, teachers are expected to be able to provide behavior modification so that students experience better changes in creative writing. These changes are based on behavior modification provided by the teacher. Thus, creative writing among students cannot be separated from the psychological context.

Based on the research results, the following conclusions were obtained. First, the difficulty of students in terms of creative writing is more dominated by psychological problems. It was seen from 81 participants, 70 people stated that psychological aspect was the most dominant in the difficulties of creative writing. Second, 65 percent of students felt that behavior modification is an effective learning strategy to increase their motivation in creative writing. Psychological problems in learning to write creatively indeed should not be ignored by teachers because these problems dominate more students in creative writing. In writing learning, a teacher must not forget that he is a psychologist, while students are clients. As a psychologist, he must be able to make clients better psychologically. Therefore, giving positive and appreciative stimulus to students is very necessary for learning. For recommendations, the results of this 
study can be used as supporting material for further researchers in relation to creative writing. In addition, the results of this study indicate that the difficulty in creative writing is not only from the learning factor but also from psychological factors.

\section{References}

Ahmadi, A. (2015). Psikologi menulis [Psychology of writing]. Yogyakarta: Ombak.

Ahmadi, A., Darni, Murdiyanto, \& Hariyati, N. R. (2019). Reader's response and learning writing psychological perspective. Art and Humanities, 8(7), 11-15.

Ahmadi, A., Ghazali, A. S., Maryaeni, \& Dermawan, T. (2019). Ecopsychology and Psychology of Literature: Concretization of Human Biophilia That Loves the Environment in Two Indonesian Novels. The International Journal of Literary Humanities, 17(1), 47-59

Ahmadi, A. , Darni, \& Murdiyanto (2019). Creative writing in higher education. International Journal of Humanities and Cultural Studies, 5(4), 1-8

Ahmadi, A, Sodiq, S., Setiawan, S., Pratiwi, Y., \& Hariyati, N. R. (2019). Learning writing through psychowriting perspective. Advance in Language and Literary Studies, 10(1), 4-8. http://dx.doi.org/10.7575/aiac.alls.v.10n.1p.4

Ashton, M. (2013). Individual differences and personality. 1st ed. Amsterdam: Academic Press.

Atlee, N. (2005). Advancing writing skills. San Luis Obispo: Dandy Lion Publication.

Awuzie, S. (2018). Creative writing as psychotherapy. Biomed Sci \& Tech Res, 8(2), 64406442. http://dx.doi.org/10.26717/BJSTR.2018.08.001636.

Berman, J. (2003). The writing cure: How expressive writing promotes health and emotional well-being. Psychoanalytic Psychology, 20(3), 575-578. http://dx.doi.org/10.1037/0736-9735.20.3.575

Barbeiro, L. (2005). Writing in a circle of stories. The Reading Teacher, 59, 380-382. http://dx.doi.org/10.1598/RT.59.4.7

Baroudy, I. (2008). Process writing: successful and unsuccessful writers; discovering writing behaviours. IJES, 8(2), 43-63

Billig, M. (2011). Writing social psychology: Fictional things and unpopulated $\begin{array}{llll}\text { texts. British Journal of Social Psychology,50(1), } & 4-20 .\end{array}$ http://dx.doi.org/10.1111/j.2044-8309.2010.02003.x

Bueno, B. (2018). Creative writing in Brazil: personal notes on a process. New Writing, 15(2), 140-147. https://doi.org/10.1080/14790726.2017.1418385

Cabell, S. Q. , Tortorelli, L. S., \& Gerde, H. K. (2013). How do I write...?. The Reading Teacher, 66(8), 650- 659. http://dx.doi.org/ 10.1002/trtr.1173

Carducci, B. (2009). The psychology of personality, 1st ed. Malden, MA: Wiley-Blackwell.

Creswell, J. W. (1994). Research design: Qualitative \& quantitative approaches. Thousand Oaks, Calif: Sage Publications.

Creswell, J. W., \& Guetterman, T. C. (2019). Educational research: Planning, conducting, and evaluating quantitative and qualitative research. New York: Pearson.

Crowne, D. (2007). Personality theory. 1st ed. Don Mills, Ont.: Oxford University Press.

Darmawan, D., Hartati, T., \& Mulyasari, E. (2013). Video streaming for creative writing at international elementary school. Journal of Education and Learning, 7(1), 43-56.

Dunn, D. (1994). Lessons learned from an interdisciplinary writing course: implications for student writing in psychology. Teaching of Psychology, 21(4), 223-227. http://dx.doi.org/10.1207/s15328023top2104_4

Engler, B. (2013). Personality theories. 1st ed. Wadsworth Pub Co. 
Emily, S. (2009). Writing the personal as research. Narrative Inquiry, 19(1), 35-51. https://doi.org/10.1075/ni.19.1.03sch

Eysenck, H. (1997). Personality and experimental psychology: The unification of psychology and the possibility of a paradigm. Journal of Personality and Social Psychology, 73(6), 1224-1237.

Feist, J., \& Feist, G. J. (2006). Theories of personality. 6th Edition. New York: McGraw Hill.

Forgeard, M. J., Kaufman, S. B., \& Kaufman, J. C. (2013). The psychology of creative writing. In G. Harper (Ed.) A Companion to creative writing (pp. 320-333). Oxford: Blackwell.

Freud, S. (1910). The origin and development of psychoanalysis. New York: Nervous and Mental Disease Pub. Co.

Freud, S. (1955). The interpretation of dreams. New York: Basic Books.

Gardner, P. (2014). Becoming a teacher of writing: Primary student teachers reviewing their relationship with writing. English Educ, 48, 128-148. https://doi.org/10.1111/eie.12039

Greene, M. J. (2005). Teacher as counselor: enhancing the social, emotional, and career development of gifted and talented students in the classroom. Gifted Education International, 19(3), 226-235. https:// doi.org/10.1177/026142940501900305

Gross, R. (2010). Psychology: The science of mind and behaviour 6th Edition. London: Taylor \& Francis.

Hall, C. S., Lindzey, G., \& Campbell, J. B. (1998). Theories of personality. New York: J. Wiley \& Sons.

Jagaiah, T., Howard, D., \& Olinghouse, N. (2019). Writer's checklist: a procedural support for struggling writers. The Reading Teacher, 73(1), 103110. https://doi.org/10.1002/trtr.1802

Jordan-Baker, C. (2015). The philosophy of creative writing. New Writing, 12(2), 238-248. https:// doi.org/10.1080/14790726.2015.1047854

Jung, C. G. (1934). Archetypes and the collective unconscious. London: Routledge.

Jung, C. G. (1953). Four archetypes mother, rebirth, spirit, trickster. London: Routledge.

Jung, C. G. (1956). Symbols of transformation: An analysis of the prelude to a case of schizophrenia. Princeton: Princeton University Press.

Jung, C. G. (1961). Memories, dreams, reflections. New York:Vintage Books.

Jung, C. G. (1964). Man and his symbols. New York: Anchor Press Books.

Jung, C. G. (1966). Spirit in man, art, and literature: Collected works vol. 15. Princeton: Princeton University Press.

Jung, C. G. (1969). Structure \& dynamics of the psyche. Princeton: Princeton University.

Jouanna, J. (2012). Galen's reading of hippocratic ethics. In Galen's Reading of Hippocratic Ethics. (Pp. 262-282) Leiden, Netherlands: Brill. https://doi.org/10.1163/9789004232549_014

Kaufman, S. B., \& Kaufman, J. C. (Eds). (2013). The psychology of creative writing. Cambridge: Cambridge University Press.

Karlen, Y., \& Compagnoni, M. (2016). Implicit theory of writing ability: relationship to metacognitive strategy knowledge and strategy use in academic $\begin{array}{llll}\text { writing. Psychology Learning } \& \text { Teaching, 16(1), } & \text { 47-63. }\end{array}$ https://doi.org/10.1177/1475725716682887

Kesler, K. (2012). Writing with voice. The Reading Teacher, 66(1), 25-29. https://doi.org/10.1002/TRTR.01088

King, N., \& Brookes J. (2018). Thematic analysis ion organizational research. In C. Cassell, A. L. Cunliffe and G. Grandy (eds.), The Sage Handbook of qualitative business and management research methods (pp. 219-236). London: Sage. 
Labrador, F. J. (2004). Skinner and the rise of behavior modification and behavior therapy. The Spanish Journal of Psychology, 7(2), 178-187.

Lachenmeyer, J. R., \& Olson, M. E. (1990). Behaviour modification in the treatment of pseudoseizures: a case report. Behavioural Psychotherapy, 18(1), 73-78.

Natsoulas, T. (2018). Radical behaviorism. in states of consciousness: the pulses of experience. In T Natsoulas (Ed), States of the Counsciusness., (pp. 144-194). Cambridge: Cambridge University Press.

Nissani, M. (1997). Ten cheers for interdisciplinarity: the case for interdisciplinary knowledge and research. The Social Science Journal, 34(2), 201-216.

Martin, J. (2014). Psychologism, individualism and the limiting of the social context in educational psychology. In T. Corcoran (Ed), Psychology in education: Critical theory practice (pp. 167-180). Boston: Sense Publisher.

Martin, G., \& Pear, J. (2015). Behavior modification: What it is and how to do it (Tenth edition.). Boston: Pearson Education.

Miles, M. B., \& Huberman, A. M. (2014). Qualitative data analysis, a methods sourcebook, 3rd edn. Thousand Oaks, CA: Sage.

Miltenberger, R. G. (2011). Behavior modification: Principles and procedures. Belmont, CA: Thomson Wadsworth.

Pavlov, I. P. (1927). Conditioned reflexes: an investigation of the physiological activity of the cerebral cortex. Oxford, England: Oxford Univ. Press.

Piirto, J. (2009). The personalities of creativewriters. In S.B. Kaufman \& J.C. Kaufman (Eds). The Psychology of Creative Writing, (pp. 3-22) Cambridge: Cambridge University Press.

Prilleltensky, I. (2014). Education as transformation: Why and how. In T. Corcoran (Ed), Psychology in education: Critical theory practice, (pp. 17-36). Boston: Sense Publisher.

Pollington, M., Wilcox, B., \& Morrison, T. (2001). Self-perception in writing: the effects of writing workshop and traditional instruction on intermediate grade students. ReadingPsychology, 22(4), https://doi.org/10.1080/02702710127640

Ruffner, M., \& Burgoon, M. (1981). The relationship between writing style and personality structure. Newspaper Research Journal, 2(2), 28 35. https://doi.org/10.1177/073953298100200203

Russ, S. W. (2009). Pretend play, emotional processes, and developing narratives. In S.B. Kaufman \& J.C. Kaufman (Eds). The psychology of creative writing (pp. 274-263). Cambridge: Cambridge University Press.

Roth, K., \& Dabrowski, J. ( 2014). Extending interactive writing into grades 2-5. The Reading Teacher, 68(1), 33- 44. https://doi.org/10.1002/trtr.1270

Sandelowski, M. (1998). Writing a good read: Strategies for re-presenting qualitative data. Res. Nurs. Health, 21,375-382. https://doi.org/10.1002/(SICI)1098240X(199808)21:4<375::AID-NUR9>3.0.CO;2-C

Sinha, S., \& Back, L. (2014). Making methods sociable: dialogue, ethics and authorship in qualitative research. Qualitative Research, 14(4), 473-487. https://doi.org/10.1177/1468794113490717

Solheim, K. (2019). Teachers' aspirations to improve their classroom interaction. International Journal of Learning, Teaching and Educational Research, 18(6), 147-169. https:// doi.org/10.26803/ijlter.18.6.9

Silverman, D. (2000) Doing qualitative Research. London: Sage.

Skinner, B. F. (1957). Verbal behavior. New York: Appleton-Century-Crofts. 
Swander, M., Leahly, A., \& Cantrell, M. (2007). Theories of creativity and creative writing pedagogy. In Steven Earnshaw (ed.). The handbook of creative writing. Edinburg: Edinburg University Press.

Tatat, H. 2017. Conferencing approach in promoting writing ability: A classroom action research study on language creative writing in Indonesian language. Indonesian Journal of Applied Linguistics, 7(2), 294-301. https://doi.org /10.17509/ijal.v7i2.834

Wahyuni, E. (2010). Creative writing poem using interactive activity. Jurnal Humanity, 6(1), 21-27.

Wang, E., Matsumura, L. C., \& Correnti, R. ( 2017). Written feedback to support students' higher level thinking about texts in writing. The Reading Teacher, 71(1), 101- 107. http://doi.org/10.1002/trtr.1584

Watson, J. B. (1913). Psychology as the behaviorist views it. Psychological Review, 20(2), 158-177. http://doi.org/10.1037/h0074428

Wheldall, K. (1992). Contemporary behavioural perspectives in special education. Australasian Journal of Special Education,15(1-2), 2-4 https://doi.org/10.1017/S103001120002248X

Wells, T., Albright, L., Keown, K., Tkatch, R., Duffy, M., Wu, L., \& Wicker, E. (2018). Expressive writing: Improving optimism, purpose, and resilience writing and gratitude. Innovation in Aging, 2(1), 241-241. http:// doi.org/10.1093/geroni/igy023.900

Wilson, A. A. (2008). Motivating young writers through write- talks: real writers, real audiences, real purposes. The Reading Teacher, 61, 485-487. http://doi.org/10.1598/RT.61.6.5

Williams, C. (2018). Learning to write with interactive writing instruction. The Reading Teacher, 71(5), 523- 532. https://doi.org/10.1002/trtr.1643

White, R., \& Arndt, V. (1991). Process writing. London: Longman.

Yoo, J. (2017). Writing out on a limb: integrating the creative and academic writing identity. New Writing, 14(3), 44-54. https://doi.org/10.1080/14790726.2017.1317274 